\title{
The Efforts of Revitalizing and Increasing the Appreciation towards Siti Zubaidah Performance Art
}

\author{
Nurhayati
}

\begin{abstract}
Siti Zubaidah performance art is one of the performing arts in Palembang City which is almost endangered. It is not familiar to students of the Faculty of Teacher Training and Education of Sriwijaya University. This study aims to revitalize the performing art of Siti Zubaidah and increase appreciation of the students of the Faculty of Teacher Training and Education of Sriwijaya University. The method used in this research was mixed method. The quantitative data were collected by using tests and questionnaires, while the qualitative data were collected by observation and Focus Group Discussion. The collected data show that it needs revitalization of Siti Zubaidah performance art. On the other hand, the data show that there is a growing appreciation of the students on cognitive, attitude, and psychomotor aspects. Hopefully this research can continuously promote appreciation of students and people of Palembang City towards the performing arts.
\end{abstract}

Keywords-performance art, Siti Zubaidah, appreciation, revitalization

\section{INTRODUCTION}

Local culture is an identity of a region. It is the proud for local people and its existence should be maintained. The local culture as wisdom constitutes intelligence which is generated based on one's experiences so that it belongs to everybody (Rahyono, 2009:8). It may be in the forms of dances, musical instruments, folk songs, traditional houses, clothes, traditional weapons, tradition, traditional cooking, and performance arts.

Traditional performance arts known by the Indonesian people are lenong from Betawi, ludruk from East Java, and ketoprak from Middle Java. As for Palembang, the performance art is Dulmuluk and Siti Zubaidah performance art.

Dulmuluk performing art came from Abdul Muluk's poem written by Raja Ali Haji in 1846. The number of stanzas is 1818 (Saleh and Dalyono in Nurhayati, Subadiyono, Suhendi, and Sari, 2015:37). Meanwhile, Siti Zubaidah performing art came from the poem of Siti Zubaidah. It was written by Abdullah Munsyi in 1840 (Fang, 1993: 134). It consists of 3822 stanzas (Yulita, 1997: 24)

Sriwijaya University, Indonesia , Email: nurhayati@ fkip.unsri.ac.id
The poem of Siti Zubaidah was written in jail in Singapore. It is stated in the stanzas of 3200 and 3781 . The poem begins with "Bismillahirahmanirrahim This is the very wonderful poem of Siti Zubaidah".

The performing art of Dulmuluk is more familiar to Palembang community because it came first. As the time went on, Dulmuluk artists got bored with the Dulmuluk story which was performed repeatedly. At last, the artists of Palembang performance arts got an idea to perform Siti Zubaidah performance art. This performance art of Siti Zubaidah resulted from the desire of performing artists for a new variation particularly on the story aspect. Therefore, the poem of Siti Zubaidah was used as the basis of performing art story. Right now, the performance art of Siti Zubaidah still exists at certain communities in Palembang. They can be classified as the "low level" of communities such as laborers and daily workers.

Unlike the performing art of Dulmuluk that has been familiar to Palembang people in recent years, particularly to the academics, the university students of Palembang City, Siti Zubaidah is not popular to them. It is due to the lack of frequency of Siti Zubaidah performed by traditional theater groups. Although it is performed by the traditional theater, it is not managed professionally. According to Suhartini (1998) and Fajri (2003), one of the characteristics of traditional performances is lack of maximum effort of figure inspiration, vocals, stage design, cosmetology, fashion, and lighting.

Maintaining Siti Zubaidah performance art needs revitalizing efforts. According to Nurhayati, Subadiyono, Suhendi (2013:52) the efforts of revitalization are the process or manner and action to revitalize something that has ever existed, but then it loses ground. The effort revitalization is conducted by modifying the performing art of Siti Zubaidah by incorporating aspects of modern dramaturgy.

The result of survey on 25 students taking Studio Literature Course shows that all of the students were not familiar to Siti Zubaidah performing art. They had never watched it.

The performance art of Siti Zubaidah was never performed by students, especially prospective-teacher students. That is why it needs an effort to increase appreciation on Siti Zubaidah performance art for students of Faculty of Teacher Training and Education of Sriwijaya University. The increased appreciation on Siti Zubaidah performance art is needed by prospective-teacher students since they are expected to pass on the appreciation on Siti Zubaidah when they become teachers in the future. They will ask their students to maintain and 
continue the efforts of preserving Siti Zubaidah performance art.

Students of secondary schools need to learn performance arts because it has positive values. The learning of play itself can involve students in their learning intensively and enrich students' experience from various directions (Moore, 2004:3).

To improve prospective-teacher students' appreciation on Siti Zubaidah performance art, the materials of Siti Zubaidah performance art are included in the Studio Literature Course. The course is designed starting from planning, implementing, and evaluating whose main aim is that students can have appreciation on Siti Zubaidah performance art.

Squire and Taba (in Aminudin, 2013:34) conclude that appreciation involves three aspects, namely 1) cognitive, 2) emotive, and 3) evaluative. Zaidan (2001:21) states that literature appreciation takes place in a process covering understanding, enjoying, and appreciating. Nurhayati, Subadiyono, and Didi (2015:230) conclude that the attitude, cognitive, and psychomotor aspects include in the appreciation activity.

In this study, the appreciation includes cognitive, attitude, and psychomotor aspects. The cognitive aspect is related to the existence of high knowledge on the history of Siti Zubaidah performance art and the poem of Siti Zubaidah (as a basis of performing Siti Zubaidah). In the attitude aspect, the students have good attitude towards the planning, practicing, and performing of Siti Zubaidah. The aspects to be assessed in the questionnaire cover responsibility, cooperation, creativity, script writing, practicing, and performing. On the other hand, students are categorized to have appreciation on psychomotor aspect when they can perform Siti Zubaidah watched by minimally 350 people (see Nurhayati, Subadiyono, Suhendi, 2015). In addition, if the audience considers the performing of Siti Zubaidah conducted by students was interesting and wellmanaged, it means that they have improved psychomotor appreciation.

\section{RESEARCH METHODOLOGY}

The study was conducted by using mixed method. Creswell \& Plano (in Creswell, 2012:53) state that mixed method has a procedure of collecting and analyzing data by making use of data collection technique both quantitatively and qualitatively.

The quantitative data were tests (pretest dan posttest) referring to students' knowledge on arts performance and poem of Siti Zubaidah. The pretest was given before the students took the Studio Literature Course, and the posttest was given after the students took the course. The tests were given to find out students' appreciation on knowledge aspect.

Besides, the quantitative data were collected by using a questionnaire asking students' attitude in the process of planning, practicing, and performing of Siti Zubaidah. It was given to find out the students' appreciation on the attitude aspect.

The data of the test result were scored and described, while the questionnaire data were grouped, presented, and described.

The qualitative data were collected using observation technique and focus group discussion.
Observation was carried out by the audience watching the staging of Siti Zubaidah. The audience consisted of artists, academics, and students who watched the staging of Siti Zubaidah. The staging was performed by the students taking the Studio Literature Course. Observation was conducted to collect data if the staging performed by the students was successful or not and to find out the weaknesses and advantages of the staging. The aim of observation conducted by the audience was to find out the students' appreciation on the psychomotor aspect. The obtained observation data were described.

The focus group discussion was participated by artists, academics, and students. The aim of focus group discussion was to get data about revitalization of Siti Zubaidah performance art. The data were then described

\section{RESULTS AND DISCUSSION}

\section{A. Revitalization of Siti Zubaidah Performance Art}

The data obtained from the focus group discussion were related to the efforts of revitalization of Siti Zubaidah Performance Art.

The artists suggested that the time allocation for performing Siti Zubaidah was limited to 1 hour. Their reason was that the staging of Siti Zubaidah commonly performed by traditional artists by following the story line of the poem from the beginning to the end took place 3 days. The duration of staging based on the story line was divided into three parts, namely part I (stanzas 1 to 1197), part II (stanzas 1198 to 1669), and part III (stanzas 1670 to 3822). Each part needs all night from 20:30 to 03.00 . Consequently, the staging duration needs to be revitalized by shortening the story as necessary (one hour at the most) so that the audience does not get bored.

The academics suggested that the revitalization be given to the aspect of staging management. Basically, the theater of traditional Siti Zubaidah has its own staging management. For example, the director who is concurrently head of production at the same time is called the chairman of the group. This task overlaps because it unites the managerial team and the artistic team.

In modern staging, staging management is divided into managerial team and artistic team. The former includes production head, secretary, marketing, public relation or publication, consumption, and documentation (compare that of Riantiarno, 2011). The latter consists of director, script, cast, sound system, clothing, cosmetics, music system, stage layout, and audience. In this way, there will be no overlapping of the responsibility between the two. The academics also suggest that the script of staging because the traditional theaters do not get used to staging script writing. It is no wonder that the story frequently goes out of the poem of Siti Zubaidah itself.

The academics also suggest that there be a clear task division between managerial and artistic teams. As a result, all parties focus on their jobs that make everything runs successfully, starting from planning, practicing, to performing on stage. 
Academics also suggested that the performers of Siti Zubaidah who were previously men be made appropriate to the characters played. Male characters are performed by men and female characters are performed by women. This is done in order to maximize the role of figures in accordance with each characteristic.

Students suggested that the story used for performing Siti Zubaidah on stage be revitalized. Contemporary issues may be used for the staging but they are conducted through the dialog of Kadam figure. This discretion is made to have the story line appropriate to the original poem such as Ketoprak which does not eliminate the story elements of Mahabarata. Some dialogs using contemporary issues as an improvisation of Kadam can be inserted into the dialogs for educating and entertain audience so that they will not get bored although the story coming from the poem of Siti Zubaidah.

\section{B. Students' Appreciation on Siti Zubaidah Performing Art}

To measure the knowledge of the students on the performance art of Siti Zubaidah, a test was given to 25 students taking Literature Studio course. The knowledge being tested was related to the origin of Siti Zubaidah performing art, the origin of the story of Siti Zubaidah, the author of the poem of Siti Zubaidah, the number of stanzas of the poem of Siti Zubaidah, episodes of Siti Zubaidah tah can be performed on stage, the parts which are not the story of Siti Zubaidah, the parts which are not the place setting in the stage performance of Siti Zubaidah, chief of Kembayat Negara army, name of Sultan who led Kembayat Negara, and the main character in the poem of Siti Zubaidah.

The results of pretest and posttest are shown in the following graphic.

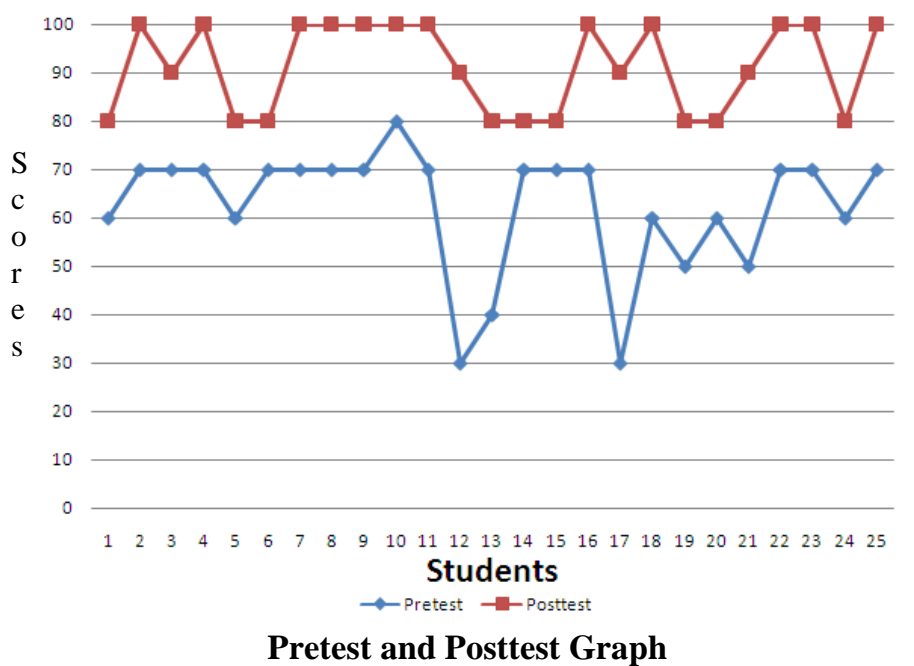

It can be concluded that in the graphic of pretest and posttest the knowledge of students on Siti Zubaidah is improved. In the pretest, the lowest score was 30 and the highest score was 80 . In the posttest, the lowest score was 80 and the highest was 100 .

Besides the knowledge aspect, the observation was conducted to the attitude of 25 students in the process of planning, practicing, and performing Siti Zubaidah on stage. It was conducted to find out the students' appreciation on the attitude aspect. The aspects to be assessed in the questionnaire covered responsibility, cooperation, creativity, script writing, practicing, and performing on stage.

In the aspect of responsibility, almost all of the students (92\%) had full responsibility, and the rest (8\%) lacked full responsibility. Full responsibility means the students attended all activities of planning, practicing, and performing Siti Zubaidah on stage. In the aspect of cooperation, almost all of the students (88\%) could cooperate in the activities of planning, practicing, and performing Siti Zubaidah on stage. In the aspect of creativity, almost all of the students (92\%) had creativity in the activities of planning, practicing, and performing Siti Zubaidah on stage. The students divided the tasks into two teams, namely managerial and artistic teams with their own tasks and functions. The two teams had high creativity indicated by all tasks were carried out well and expeditiously.

In the process of practicing which was conducted 20 times, almost all of the students (92\%) participated the practicing, while the rest participated 18 times. At the time of staging of Siti Zubaidah, all students participated.

In the aspect of script writing individually, all students $(100 \%)$ submitted the scripts.

The following data are related to Siti Zubaidah on stage performance by students. Siti Zubaidah on stage performance was one of the tasks in Literature Studio course. Staging was conducted at Graha Budaya Provinsi in Palembang in South Sumatra. It was watched by approximately 645 people. After watching it, 30 people of the audience (selected as respondents) were given a questionnaire to find out the aspects relating to the staging of Siti Zubaidah such as the overall impression of the staging, plot, interesting things, characters, settings, clothing, cosmetics, music system, lighting, theme, property, script, language and dialogue. The following are the obtained.

About $80 \%$ of the respondents stated that the staging of Siti Zubaidah was on the whole attracting. The staging management was good. The players controlled the stage well. The staging showed strong improvisation of each character. The control of the audience was excellent. Although there was no direct communication with the audience, the audience response was quite good in each scene.

About $93 \%$ of the respondents stated that the composition of plot stages (introduction, conflict raising, conflict, climax, and denouement) was managed acurately. The story line was clear. The shift of the story line was very good, the shift of rounds and scene were well-managed and chronological. The part of conflict raising was managed very well that it created accurate continuity with the conflict. The climax development was consistently maintained. The climax part was shown very strongly. Yet, the denouement part was less shown.

The respondents stated that there were things of interest in the story. There were some things interesting particularly during the action scene played by Siti Zubaidah. Siti Zubaidah 
fought troops from the Chinese Country and she was trying to release her husband who was captured by them. In addition, other interesting things were funny scenes displayed by the palace servants. Palace servants are characters representing people of low class. They are palace maids. They can discuss a variety of issues that occur around the palace or in the community. Servant characters often talk about popular issues discussed in a "funny" way that invites laughter. It is precisely the presence of servant characters that are eagerly awaited by the audience because it can "dilute" the atmosphere.

However, there was some part which was not attracting, that is a scene of finding a baby. Another uninteresting thing that occurred was a scene in the first staging, for example the appearance of a king and a queen.

About $80 \%$ of the respondents stated that in general the performed characters of the story were appropriate to each character. The characters of the staging of Siti Zubaidah performed by actors or actress were quite suitable to total appreciation. The prince, princess, king, and queen quite represented real king and queen. Motives or reasons the characters acted most in the scenes were quite clear. They were appropriate to the story line and the characters being performed. The respondents felt close to the characters that played a role. The respondents could imagine, think about, and feel what the characters felt. The characters were Sultan Abidin Syah, Siti Zubaidah, Siti Sajaroh, Chinese princess, and the servants.

About $63 \%$ of the respondents stated that the setting was arranged in accordance with the story content. Basically, the story content of Siti Zubaidah (coming from the Poem of Siti Zubaidah) talked about the life of palace (palace-centered), namely Kembayat Kingdom. According to the respondents, the throne as the setting of the stage performance already depicted the luxury of a kingdom. In addition, the choice of the background in gold color reflected the palace splendor.

About $73 \%$ of the respondents stated that the clothing was very appropriate to the figure characters. For example, the clothing worn by the king, queen, prince, and their wives were quite attracting and reflected the image of nobility. The aspect of costume was stylish and harmonious with the characters of the figures. The king, queen, sultan, sultan's wife, servants, and attendants had good makeup in accordance with their roles. In the aspect of music, $10 \%$ of the respondents stated that it was not managed well as it was supposed to be with the scenes of the story. Yet, on the whole the music reflected the scenes sufficiently.

In the aspect of lighting, $77 \%$ of the respondents stated that the lighting was harmonious with the story. The lamps functioned well. The movement of the characters was highlighted distinctively by the lamps. When the character was sad, the red lamp was lit. When the character was happy, the lamp got yellow brightly. The faces of the characters changed from one scene to another were quite obvious assisted by the good lamp system. The players were easily identified with the lamps that were functionalized well. The players were at the right spot light.

Fifty-three percents of the respondents stated that the theme was quite relevant with the current condition. For example, the humor used by the servants in the dialog. But, in the aspect of conflict related to the theme, the respondents stated that the conflict experienced by the characters was not experienced by the respondents. The reason is that most of the story was about the kingdom whose conflict was not felt by the respondents as the audience.

Ninety-three percents of the respondents stated that the existing property and hand property on the stage were functionalized by the players well. However, on the whole, they were only used by the servant figures.

In the aspect of the script, $73 \%$ of the respondents stated that on the whole the script was good. Yet, the narration seemed slow that made the story a little bit confusing. In the aspect of language and the dialog, $73 \%$ of the respondents stated that the existing language and the dialog were considered appropriate to the characters. The actors and actresses used the language well, although it was somewhat exaggerated in the parts of the servant characters/attendants that looked too coquettish. The respondents also stated that the pronunciation spoken by the characters was clearly heard. However, some players did not pronounced quite clearly such as the clothing seller.

Viewed from the respondent data, the students' appreciation of the psychomotor aspect got improved. It was indicated by the success of their performance on stage. Those who did not take the Literature Studio Course previously, could perform Siti Zubaidah on stage well after they took it. There are two indicators of the existence of students' appreciation in the psychomotor aspect, namely there were many spectators watching Siti Zubaidah staging (645 spectators) and the respondents stated that the whole performance on stage was attracting and managed well.

\section{CONCLUSION}

The results of the study show that the performance art of Siti Zubaidah needs to be revitalized. Parts that need to be revitalized are time allocation of the staging, staging management, figure characters, and raised issues.

The results of the study also show that there is improvement of the students' appreciation on the performing art of Siti Zubaidah in the cognitive, attitude, and psychomotor aspects.

There should be a sustainability of the performing art of Siti Zubaidah as an asset of local culture of Palembang City. The most effective efforts to sustain it are obviously through education or schooling. Nevertheless, without the help and concern of various parties, particularly the regional government, the efforts will be in vain. Therefore, it is expected to have continuous and significant assistance of the regional governments for the sake of the sustainability of the performing arts and their artists. 


\section{REFERENCES}

[1] F.X. Rahyono, Kearifan Budaya dalam Kata. Jakarta: Wedatama Widya, 2009, p. 8.

[2] Nurhayati, Subadiyono, D. Suhendi, and A. Sari, Kreatif Memproduksi Naskah Dulmuluk Modern. Palembang: Noer Fikri, p. 37.

[3] L. Y. Fang, Sejarah Kesusastraan Melayu Klasik, Jilid 2. Jakarta, 1993, p. 134.

[4] N. L. Yulita, Syair Siti Zubaidah: Suntingan Naskah dan Analisis Tokoh Wanita. Inderalaya: FKIP Universitas Sriwijaya, 1997, unpublished undergraduate thesis).

[5] Suhartini. Perbandingan Seni Pertunjukan Teater Dulmuluk pada Tunas Harapan di Kodya Palembang dan Grup Bintang Fajar di Kabupaten Ogan Komering Ilir Propinsi Sumatera Selatan. Bandung: Sekolah Tinggi Seni Indonesia, 1998, unpublished undergraduate thesis.

[6] M. Fajri, Mengenal Kesenian tradisional Sumatera Selatan (Dulmuluk). Palembang, 2003, unpublished.

[7] Nurhayati, Subadiyono, and D. Suhendi, "Dulmuluk traditional performance art: revitalization and student's appreciation," Litera, vol. 14, no. 2, pp. 229-238, Oct. 2015.

[8] M.M. Moree. Using Drama as An Effective Method to Teach Elementary Students, http://commons.emich.edu. 2004, (accessed September 21, 2015

[9] Aminudin, Pengantar Apresiasi Karya Sastra. Bandung: Sinar Baru Algensindo, 2013, p. 34.

[10] Zaidan, Pedoman Penyuluhan Apresiasi Sastra. Jakarta: Depdiknas, 2001, p. 21

[11] Nurhayati, Subadiyono, and D. Suhendi, Revitalisasi Seni Pertunjukan Dulmuluk. Yogyakarta:LeutikaPrio, 2013, p. 52.

[12] J.W. Creswell, Educational Research: Planning, Conducting, and Evaluating Quantitative and Qualitative Research (fourth edition). Boston, MA: Pearson, 2012, p. 535. 